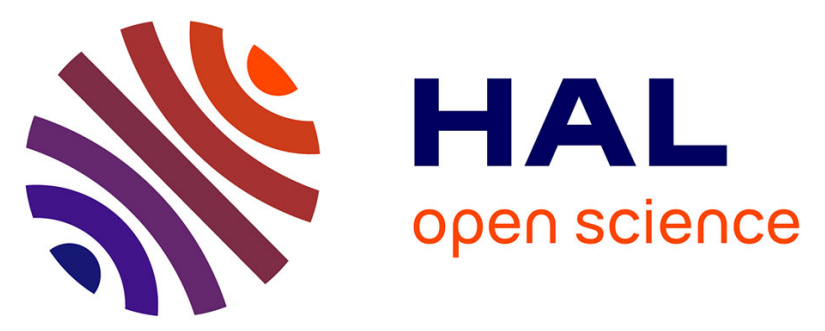

\title{
Isotopic values of the Amazon headwaters in Peru: comparison of the wet upper Río Madre de Dios watershed with the dry Urubamba-Apurimac river
} system

Luc Lambs, Aline Horwath, Thierry Otto, Frédéric Julien, Pierre-Olivier Antoine

\section{To cite this version:}

Luc Lambs, Aline Horwath, Thierry Otto, Frédéric Julien, Pierre-Olivier Antoine. Isotopic values of the Amazon headwaters in Peru: comparison of the wet upper Río Madre de Dios watershed with the dry Urubamba-Apurimac river system. Rapid Communications in Mass Spectrometry, 2012, vol. 26, pp.775-784. 10.1002/rcm.6157 . hal-00955671

\section{HAL Id: hal-00955671 \\ https://hal.science/hal-00955671}

Submitted on 5 Mar 2014

HAL is a multi-disciplinary open access archive for the deposit and dissemination of scientific research documents, whether they are published or not. The documents may come from teaching and research institutions in France or abroad, or from public or private research centers.
L'archive ouverte pluridisciplinaire HAL, est destinée au dépôt et à la diffusion de documents scientifiques de niveau recherche, publiés ou non, émanant des établissements d'enseignement et de recherche français ou étrangers, des laboratoires publics ou privés. 


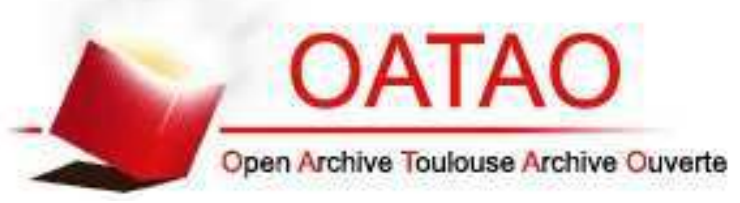

\section{Open Archive TOULOUSE Archive Ouverte (OATAO)}

OATAO is an open access repository that collects the work of Toulouse researchers and makes it freely available over the web where possible.

This is an author-deposited version published in : http://oatao.univ-toulouse.fr/ Eprints ID : 11079

To link to this article :

DOI: $10.1002 / \mathrm{rcm} .6157$

URL : http://dx.doi.org/10.1002/rcm.6157

\section{To cite this version :}

Lambs, Luc and Horwath, Aline and Otto, Thierry and Julien, Frédéric and Antoine, Pierre-Olivier Isotopic values of the Amazon headwaters in Peru: comparison of the wet upper Rio Madre de Dios watershed with the dry Urubamba-Apurimac river system. (2012) Rapid Communications in Mass Spectrometry, vol. 26 ( $\mathrm{n}^{\circ} 7$ ). pp. 775-784. ISSN 0951-4198

Any correspondance concerning this service should be sent to the repository administrator: staff-oatao@ listes-diff.inp-toulouse.fr 


\title{
Isotopic values of the Amazon headwaters in Peru: comparison of the wet upper Río Madre de Dios watershed with the dry Urubamba-Apurimac river system
}

\author{
L. Lambs ${ }^{1 *}$, A. Horwath ${ }^{2}$, T. Otto ${ }^{1}$, F. Julien ${ }^{1}$ and P.-O. Antoine ${ }^{3}$ \\ ${ }^{1}$ Ecolab UMR 5245 CNRS-UPS-INPT, 118 route de Narbonne, F-31062 Toulouse Cedex, France \\ ${ }^{2}$ Department of Plant Sciences, University of Cambridge, Downing Street, Cambridge CB2 3EA, UK \\ ${ }^{3}$ ISEM, UMR 5554 CNRS, CC064, Université Montpellier 2, Place Bataillon, F-34095 Montpellier Cedex, France
}

RATIONALE: The Amazon River is a huge network of long tributaries, and little is known about the headwaters. Here we present a study of one wet tropical Amazon forest side, and one dry and cold Atiplano plateau, originating from the same cordillera. The aim is to see how this difference affects the water characteristics.

METHODS: Different kind of water (spring, lake, river, rainfall) were sampled to determine their stable isotopes ratios (oxygen 18/16 and hydrogen 2/1) by continuous flow isotope ratio mass spectrometry (IRMS). These ratios coupled with chemical analysis enabled us to determine the origin of the water, the evaporation process and the water recycling over the Amazon plain forest and montane cloud forest.

RESULTS: Our study shows that the water flowing in the upper Madre de Dios basin comes mainly from the foothill humid forest, with a characteristic water recycling process signature, and not from higher glacier melt. On the contrary, the water flowing in the Altiplano Rivers is mainly from glacier melts, with a high evaporation process. This snow and glacier are fed mainly by Atlantic moisture which transits over the large Amazon forest.

CONCLUSIONS: The Atlantic moisture and its recycling over this huge tropical forest display a progressive isotopic gradient, as a function of distance from the ocean. At the level of the montane cloud forest and on the altiplano, respectively, additional water recycling and evaporation occur, but they are insignificant in the total water discharge. Copyright

The Amazon is the biggest river in the world. It originates in the Andes and travels westward about $6400 \mathrm{~km}$ to the river mouths on the Atlantic Ocean near the Equator. The surface area of the Amazon rainforest is so vast that it has its own specific physical properties. The first studies of the meteorology and hydrology of the Amazon measured fundamental climatological parameters such as temperature, precipitation, solar radiation, and winds. ${ }^{[1-4]}$ From various scale analyses, it was calculated that up to $50 \%$ of the Amazon precipitation evaporates into the atmosphere, while the remainder flows out via run-off. These results clearly indicate the importance of the forest in maintaining the water balance in the basin. ${ }^{[5]}$ The Amazon's hydrological recycling originates from nonfractionating sources for stable isotopes in transpiration and canopy re-evaporation. This moisture recycling within the Amazon basin leads to a seasonally averaged gradient of only $1.5 \% / 1000 \mathrm{~km}$ in $\delta^{18} \mathrm{O}$ values going inland from east to west (i.e. upstream). For comparison, the corresponding gradient is $2 \% / 1000 \mathrm{~km}$ in Europe and elsewhere. ${ }^{[6]}$

* Correspondence to: L. Lambs, Ecolab UMR 5245 CNRS-UPSINPT, 118 route de Narbonne, F-31062 Toulouse Cedex, France.

E-mail: luc.lambs@univ-tlse3.fr; luclambs@aol.com
The Amazon basin recycles about half its rainfall, with a water recycling time of about 5.5 days. ${ }^{[7]}$ Although field measurements of isotopes within the canopy ${ }^{[8,9]}$ are somewhat contradictory, the most likely sources of the observed differences are different moisture sources ${ }^{[10]}$ and the fate of water intercepted by the canopy. ${ }^{[11]}$ In a complete simulation of the Amazon's forest hydrology, the land-surface must correctly partition the moisture fluxes between water evaporation (fractionating), transpiration (non-fractionating), re-evaporated canopy-intercepted rainfall (non-fractionating if complete) and runoff. ${ }^{[12-14]}$

For the 1965-1990 period, Henderson-Sellers et al. detected statistically significant changes in the water isotopic signatures of central Amazonia. ${ }^{[15]}$ The differences which were observed in deuterium excess were found to be consistent with recent global climate model simulations only if there had been a relative increase in evaporation from non-fractionating water sources over the investigated period. ${ }^{[15]}$ The same authors found no significant change in dry season isotopic characteristics, which completely contradicts earlier predictions of the impact of such landuse changes. They concluded from this that the pre-1990 Amazonian stable isotope record was more consistent with the predictable effects of greenhouse warming (possibly combined with forest removal) than with the modelpredicted effects of deforestation alone. 
Recent stable water isotope records in the upper Amazon basin, at Izobamba (3058 m above sea level [ASL], Ecuador) and Bogotá (2640 m ASL, Colombia) have been analyzed by McGuffie and Henderson-Sellers. ${ }^{[16]}$ In the 1990s and 2000s, significant enhanced depletions for heavy isotopes in wet months were found in both locations. At Izobamba, the largest depletions have recently become still greater, while the smallest depletions have tended to diminish. At Bogotá, wet season depletions have also increased while the dry season results show no change. Hydrological catchment model results compared with the Izobamba data suggest that the recently observed increased isotopic spread could be explained by less non-fractionating evaporation (transpiration and canopy re-evaporation) by the forest canopy. These very recent changes in $\delta^{18} \mathrm{O}$ and $\delta \mathrm{D}$ signatures demonstrate the impact of deforestation: vegetation removal prompting less recycling and less re-insertion of heavy isotopes into the basin's hydrological system. Longer records will be needed to distinguish between anthropogenic trends and natural climate variability.

The water fluxes between land and atmosphere are important facets in the spatially and temporally complex hydrological cycle of the Amazon Basin. This cycle also extends to the global scale, as condensational energy (the heat needed to put together droplets in a cloud) released by convective precipitation within the basin has been shown to be of sufficient magnitude to have an impact upon global climate patterns. ${ }^{[5,17,18]}$

Useful information can also be gained in the tropical glaciers surrounding the Amazon headwaters. ${ }^{[19]}$ Highly resolved quantified climate proxies in the tropics can be obtained from the Andean ice cores. This is mainly because the convectively active areas in the tropics are key regions for the global hydrological cycle. In addition, there are fewer long-term meteorological stations at low latitudes than at higher northern latitudes. Determining the causes of ongoing climate shifts is therefore particularly difficult in this part of the world. ${ }^{[20]}$ The variability of the isotopic composition of precipitation over tropical South America, with a view to interpreting the Andean ice core records properly, has been discussed by several authors. ${ }^{[21-23]}$ As so many factors affect the isotopic composition there is a real need to obtain information about the isotopic variation on the lower altitude orographic obstacles.

We have studied isotopic water characteristics in the confluence between the Urubamba/Apurimac Rivers upper basin on the Ucayali upper watershed on the Altiplano, and the Madre de Dios River with its tributaries on the Amazon tropical forest side. This area is where continuous wet conditions in western Amazonia (up to $4000 \mathrm{~mm} /$ year), and the notable variation in air moisture, occur at the contact zone with the eastern Andes, giving rise to montane cloud forest between 1500 and $3600 \mathrm{~m}$. This climatic phenomenon produces a high diversity hotspot, ${ }^{[24]}$ and strongly affects the isotopic composition of the water vapor, as is seen in the local rainfall and river outflows.

\section{EXPERIMENTAL}

\section{Field sites}

Water samples along the Upper Madre de Dios River were taken during an 'ecoSystems in the Paleogene of AMazonia' program (SPAM) boat cruise in August 2009, i.e. dry season with low water levels. River samples were gathered from both the Madre de Dios River and its main tributaries, from the village of Atalaya (542 m ASL) down to the city of Puerto Maldonado (196 m ASL). A few river samples were also taken on the way through the Cordillera de Vilcanota, i.e. from Cusco (3040 m ASL) down to Bosque Nublaco (1470 m ASL).

Other water samples were taken on the Altiplano (from 1860 to $3850 \mathrm{~m} \mathrm{ASL}$ ), in order to investigate the waters of (i) the Urabamba and Apurimac valleys, and the Titicaca Lake area (Amazon headwaters), and (ii) the Arequipa area (western Andes: rivers flowing westward down to the Pacific Ocean). The locations are given in Figs. 1(a) and 1(b), and the details in Table 1.

\section{Climatic patterns}

The rainfall data samples used to calculate the local meteoric water line (LMWL) were collected between April and October 2009 along the upper Madre de Dios basin from nine rainfall gauges installed between 190 and 3640 m ASL (see Fig. 1(b)).

The general climatic features of the upper Madre de Dios, in the form of mean annual values, were taken from various weather stations located close to our sampling areas; SENHAMI, Servicio Nacional de Meteorologia e Hidrologia; ${ }^{[25]}$ ABERG, Andes Biodiversity and Ecosystem Research Group; ${ }^{[26]}$ Atrium is a database provided by 'The Botanical Research Institute of Texas'. ${ }^{\text {[2] }}$

The Peruvian climate has two main seasons: a pronounced dry period during the austral winter (May to September) and a rainy period in the austral summer where $75 \%$ of the annual rainfall occurs. The mean annual maximum rainfall (3086 mm) is observed at $950 \mathrm{~m}$, just before the cloud immersion zone from 1500 to $3600 \mathrm{~m}$ (MAP: Fig. 2(a)). There is almost no variation in temperature over the season (data not shown), but a mean decrease in temperature of $0.6{ }^{\circ} \mathrm{C}$ per $100 \mathrm{~m}$ of elevation (MAT: Fig. 2(a)). The high level of air moisture, close to saturation, explains this low value. The mean annual relative humidity (MARH: Fig. 2(b)) remains high at all elevations. By contrast, the mean annual vapor pressure deficit (MAVPD: Fig. 2(b)) clearly delineates the two climatic zones: the lower basin (200-950 m) with high VPD values, and the upper basin (2000-3600 m) with low VPD values and a permanent cloud immersion zone. The $1500 \mathrm{~m}$ high zone with a medium VPD value is an intermediate area with no permanent fog or cloud presence.

On the Atiplano, the climate is drier with a mean annual rainfall of $671 \mathrm{~mm}$ in Cusco and $576 \mathrm{~mm}$ in Puno (Lake Titicaca). Only about $7 \%$ of the annual rainfall is received in the dry season (May to September). The mean annual temperature is also low, respectively, $12.3{ }^{\circ} \mathrm{C}$ and $9.8{ }^{\circ} \mathrm{C}$. The Pacific coast at the level of Arequipa is the driest part, with less than $100 \mathrm{~mm}$ rainfall per year and with a mean temperature of $14.9^{\circ} \mathrm{C}$.

\section{Stable isotopes}

The waters for isotopic analysis were collected in $10 \mathrm{~mL}$ glass vials with secure caps ready to be sent to the isotopic analysis laboratory. The stable isotope composition of water is reported with reference to the Vienna Standard Mean Ocean Water (V-SMOW) and the Vienna Standard Light Antarctica Precipitation (V-SLAP), in parts per thousand. The definition for oxygen is: 
(a)

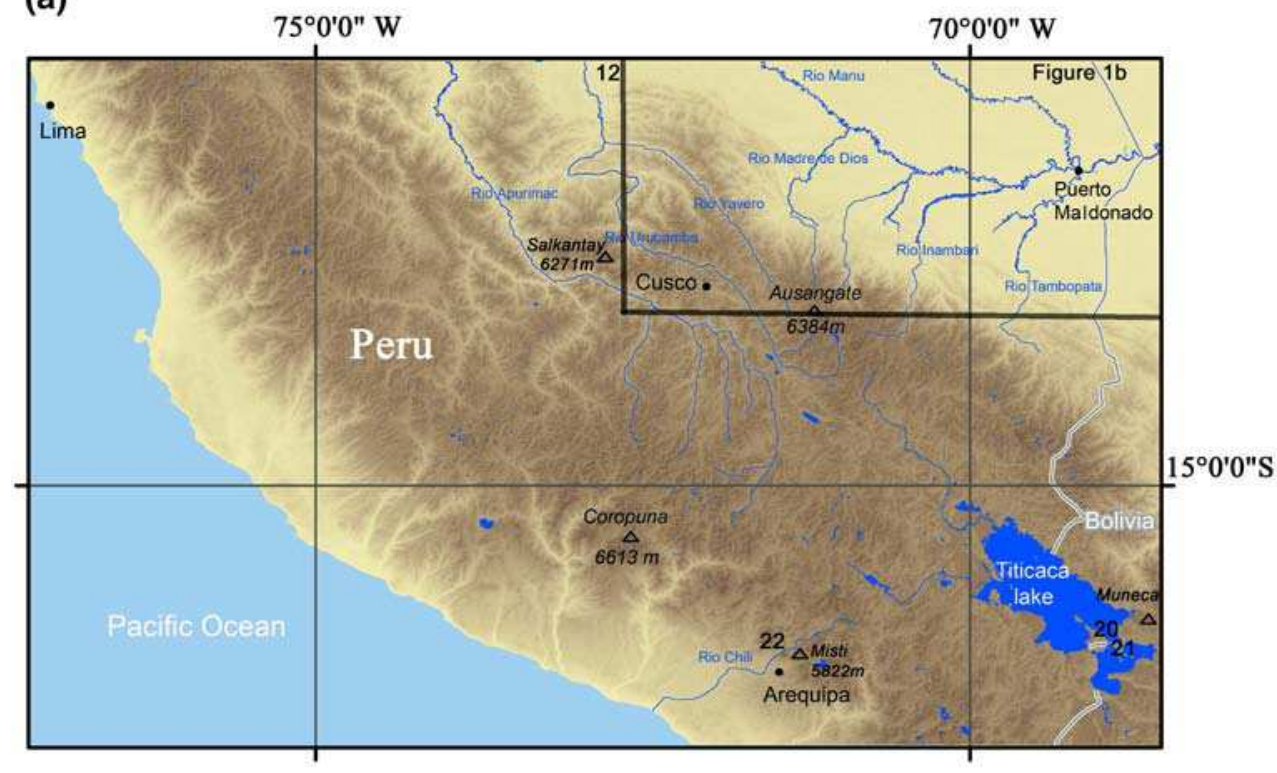

(b)

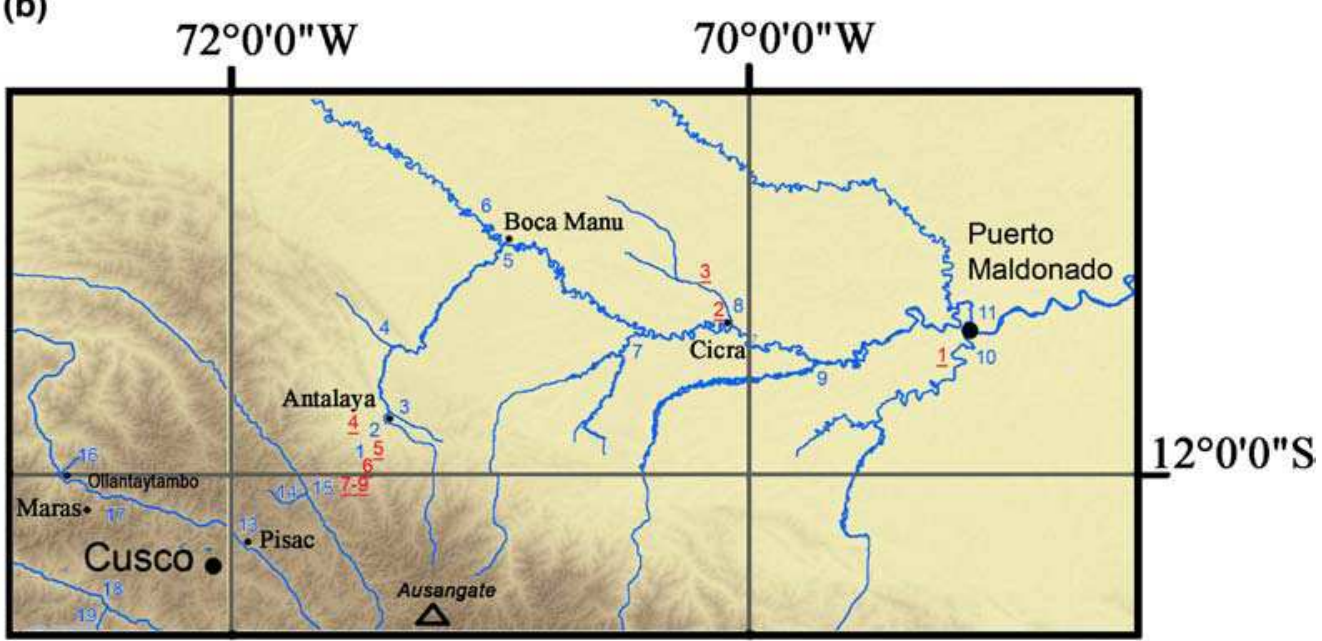

Figure 1. (a) General map of the studied area around the city of Cusco, enclosed by the Apurimac and Urubamba rivers. The Rio Madre de Dios and tributaries are located north-east and are enlarged in (b). (b) Location of the rivers basins, sampling sites (blue numbers), and the rainfall collection sites (red numbers) along the Madre de Dios upper watershed.The numbers correspond to the sampling place according to Table 1 .

$\delta^{18} \mathrm{O}_{\text {V-SMOW }}(\%)=\left(\left({ }^{18} \mathrm{O} /{ }^{16} \mathrm{O}_{\text {sample }}\right) /\left({ }^{18} \mathrm{O} /{ }^{16} \mathrm{O}_{\text {standard }}\right)-1\right) * 1000$;

and for deuterium:

$\delta^{2} \mathrm{H}_{\mathrm{V} \text {-SMOW }}(\%)=\left(\left({ }^{2} \mathrm{H} /{ }^{1} \mathrm{H}_{\text {sample }}\right) /\left({ }^{2} \mathrm{H} /{ }^{1} \mathrm{H}_{\text {standard }}-1\right) * 1000\right.$.

These river water measurements were carried out at the Iso-analytical Laboratory, Crewe, UK. For the saltwater samples (e.g., in Maras Spring; Table 1), vacuum distillation was carried out prior to the isotopic analysis. The water samples were measured by continuous flow on a classical Geo20-20 isotope ratio mass spectrometer, after equilibration on an ANCA-GSL preparation module. Both instruments are from PDZ Europa, Crewe, UK. The mass spectrometer is fitted with a long spur flight tube which separates hydrogen from helium in the mass spectrometer. Three working laboratory standards were used: IA-R052, IA-R053 and IA-R054. All are traceable to V-SMOW2/ V-SLAP2, the international standards provided by the IAEA, Vienna, Austria. Each water sample was measured in triplicate for each isotope ratio. The overall mean standard deviation (sd) for the $\delta^{18} \mathrm{O}$ values was around $\pm 0.1 \%$, and the mean sd for the $\delta^{2} \mathrm{H}$ values was $\pm 1.0 \%$.

The rainfall water measurements were conducted at the Godwin Laboratory, Department of Geosciences, University of Cambridge (Cambridge, UK) using a L1102I near-infrared laser isotope ratio spectrometer, (Picarro Inc., Sunnyvale, CA, USA). The $2 \mu \mathrm{L}$ water sample was injected into the vaporization chamber and then passed 
Table 1. Detail on the water sampling, isotope results and d-excess calculation

\begin{tabular}{|c|c|c|c|c|c|c|c|c|}
\hline & Water type & Name & Place & $\begin{array}{l}\text { Altitude } \\
\text { (m ASL) }\end{array}$ & $\begin{array}{l}\text { Conductivity } \\
\qquad(\mu S)\end{array}$ & $\begin{array}{c}\delta^{18} \mathrm{O} \\
\mathrm{V}-\mathrm{SMOW} \\
(\%)\end{array}$ & $\begin{array}{c}\delta^{2} \mathrm{H} \\
\text { V-SMOW } \\
(\%)\end{array}$ & d-excess \\
\hline 1 & rivelet & Bosque Nublaco & Bosque Nublaco & 1470 & 39 & -10.47 & -76.05 & 7.74 \\
\hline 2 & main river & Rio Madre de Dios 1 & Atalaya & 542 & 63 & -10.40 & -65.90 & 17.30 \\
\hline 3 & $\begin{array}{l}\text { tributary } \\
\text { river }(\mathrm{R})\end{array}$ & Rio Carbone & Atalaya & 542 & 160 & -9.21 & -59.14 & 14.54 \\
\hline 4 & $\begin{array}{l}\text { tributary } \\
\text { river }(\mathrm{L})\end{array}$ & Rio Aquacaliente & confluence & 408 & 89 & -10.19 & -66.48 & 15.02 \\
\hline 5 & main river & Rio Madre de Dios 2 & $\begin{array}{l}\text { confluence rio } \\
\text { Manu }\end{array}$ & 286 & 97 & -9.55 & -67.33 & 9.08 \\
\hline 6 & $\begin{array}{l}\text { tributary } \\
\text { river }(\mathrm{L})\end{array}$ & Rio Manu & confluence & 282 & 244 & -6.14 & -50.17 & -1.01 \\
\hline 7 & $\begin{array}{l}\text { tributary } \\
\text { river }(R)\end{array}$ & Rio Colorado & confluence & 267 & 60 & -8.69 & -57.94 & 11.61 \\
\hline 8 & $\begin{array}{l}\text { tributary } \\
\text { river }(\mathrm{L})\end{array}$ & Rio Los Amigos & confluence & 244 & 109 & -5.88 & -42.31 & 4.74 \\
\hline 9 & $\begin{array}{l}\text { tributary } \\
\text { river }(R)\end{array}$ & Rio Inambari & confluence & 211 & 55 & -9.08 & -58.07 & 14.61 \\
\hline 10 & $\begin{array}{l}\text { tributary } \\
\text { river }(R)\end{array}$ & Rio Tambopata & $\begin{array}{l}\text { Puerto } \\
\text { Maldonado }\end{array}$ & 200 & 54 & -7.77 & -49.49 & 12.68 \\
\hline 11 & main river & Rio Madre de Dios 3 & $\begin{array}{l}\text { Puerto } \\
\text { Maldonado }\end{array}$ & 196 & 100 & -8.32 & -55.81 & 10.72 \\
\hline 12 & rivelet & Contamana & Contamana & 146 & 329 & -7.18 & -45.44 & 12.04 \\
\hline 13 & main river & $\begin{array}{l}\text { Vilcanato } \\
\text { (Urubamba) }\end{array}$ & Pisac & 3040 & 1249 & -14.33 & -116.42 & -1.76 \\
\hline 14 & $\begin{array}{l}\text { tributary } \\
\text { river }(R)\end{array}$ & $\begin{array}{l}\text { triburary of Rio } \\
\text { Mapacho }\end{array}$ & Colquepata & 2920 & 319 & -15.21 & -119.65 & 2.00 \\
\hline 15 & $\begin{array}{l}\text { tributary } \\
\text { river }(R)\end{array}$ & $\begin{array}{l}\text { Rio Yavero } \\
\text { Mapacho }\end{array}$ & Paucartambo & 2904 & 329 & -15.71 & -122.38 & 3.33 \\
\hline 16 & $\begin{array}{l}\text { tributary } \\
\text { rivelet }(\mathrm{R})\end{array}$ & Rio Ollamtaytambo & Ollamtaytambo & 2862 & 302 & -14.15 & -105.88 & 7.34 \\
\hline 17 & $\begin{array}{l}\text { tributary } \\
\text { rivelet }(\mathrm{L})\end{array}$ & salty spring Maras & Maras & 3360 & 225 per mil & -14.93 & -106.33 & 13.11 \\
\hline 18 & main river & Rio Apurimac & Puente Cunyac & 1860 & 642 & -15.60 & -121.25 & 3.58 \\
\hline 19 & $\begin{array}{l}\text { tributary } \\
\text { rivelet }(\mathrm{L})\end{array}$ & $\begin{array}{l}\text { rivelet Of Rio } \\
\text { Apurimac }\end{array}$ & Puente Cunyac & 1870 & 361 & -13.67 & -106.79 & 2.57 \\
\hline 20 & spring & spring Isla del Sol & Isla del Sol & 3850 & 321 & -16.04 & -119.57 & 8.75 \\
\hline 21 & lake & Titicaca Isla del Sol & Isla del Sol & 3812 & 1301 & -3.91 & -51.74 & -20.47 \\
\hline 22 & river & Rio Chili & Arequipa & 2438 & 193 & -15.64 & -125.86 & -0.70 \\
\hline
\end{tabular}

into an infrared absorbance cavity. Both isotope ratios can be obtained simultaneously on the same measurement. The isotope ratios were calculated from the spectral absorbance at specific wavelengths using wavelengthscanned cavity ring-down spectroscopy (WS-CRDS). Each sample was injected nine times into the vaporizer. Memory effects from previous samples were avoided by rejecting the first three analyses. Values for the final six injections were averaged with in-run precision of less than $\pm 0.1 \%$ for the $\delta^{18} \mathrm{O}$ values and $\pm 1.0 \%$ for the $\delta^{2} \mathrm{H}$ values (1-standard deviation). Calibration of results to V-SMOW was achieved by analyzing internal standards before and after each set of seven or eight samples. Internal standards were calibrated against V-SMOW2.

The deuterium excess was calculated using the Global Meteorological Water Line (GMWL) as defined by Craig ${ }^{[28]}$ and completed by Dansgaard: ${ }^{[29]}$

$$
\text { d-excess }=\delta^{2} \mathrm{H}-8 \times \delta^{18} \mathrm{O} \text {. }
$$

\section{Ion analysis}

The conductivity was measured with a 531 portable ion-meter (Consort, Turnhout, Belgium). The cation and anion concentrations, as well as the organic acids, were determined on a Dionex system (Dionex/Thermo Fisher Scientific Inc., Sunnyvale, CA, USA) on a separate $0.5 \mathrm{~mL}$ sample. For the cations, a DX-500 model was used with a Dionex CS16 $5 \times 250 \mathrm{~mm}$ column. For the anions a DX-120 model was used with a Dionex AS11-HC $4 \times 250 \mathrm{~mm}$ column.

The alkalinity was obtained from a titration against $\mathrm{HCl}$ with a 716 DMS Titrino titrimeter (Metrohm, Villebon Courtaboeuf, France). 
(a)

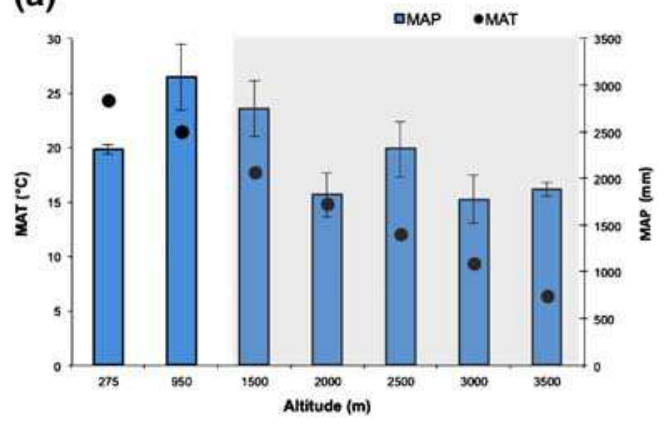

(b)

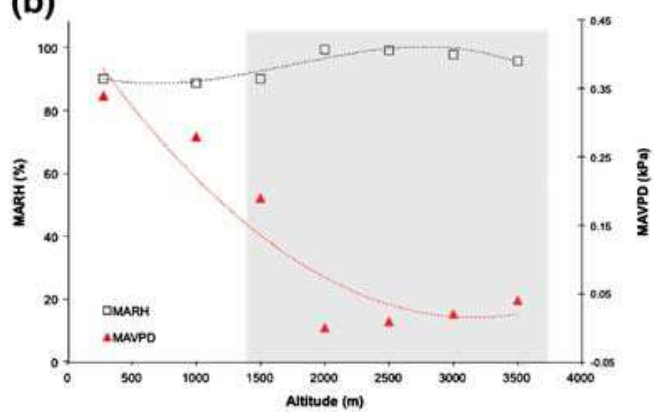

Figure 2. (a) Mean annual air temperature (MAT: closed circles) and mean annual precipitation (MAP: bars) in function of altitude for the upper Madre de Dios basin from different local meteorological stations. (b) Mean annual relative humidity (MARH: squares) and mean annual vapour pressure deficit (MAVPD) for the same area. Shading marks the observed cloud immersion zone.

\section{RESULTS}

Figure 3(a) shows the isotopic pattern of the rainfall during the dry season itself (June to August 2009) and both the interesting transitions of wet to dry (April-May) and dry to wet (September-October). The slope of these three seasons taken in chronological order decreases from 7.2 to 5.0, whereas the intercept increases from 5.5 to 13.4. Nearly all the points are above the Global Meteoric Water Line (GMWL), and these points shift as a function of the season. The overall regression line for these 151 points gives a slope of 7.92 and an intercept of 15.45 with good correlation $\left(R^{2}=0.99\right)$. This line could be taken as the Local Meteoric Water Line (LMWL) during April to October, which corresponds to 32 to $58 \%$ of the total annual rainfall as a function of the altitude. By plotting these points according to altitude strata, we can distinguish the characteristics of the different precipitation regimes, such as those coming from the Amazon basin (190-300 m), and its modification by the cloud forest $(1500-3600 \mathrm{~m})$, with a transition zone $(950-1500 \mathrm{~m})$. The values found for the lower altitude, i.e. a slope of 7.66 and an intercept of 9.06, are very similar to those of the GMWL, whereas the upper strata values display slightly higher slopes (8.4 and 8.2), but substantially higher intercept values (19.34 and 20.31).

The river water isotopic results are given in Table 1 and in Fig. 3(b). The isotope values decrease with altitude both for the Madre de Dios $\left(\delta^{18} \mathrm{O}=-10.5\right.$ up to $-8.3 \%$ ) and its Andean tributaries $\left(\delta^{18} \mathrm{O}=-10.2\right.$ up to $-7.8 \%$ ), whereas (a)

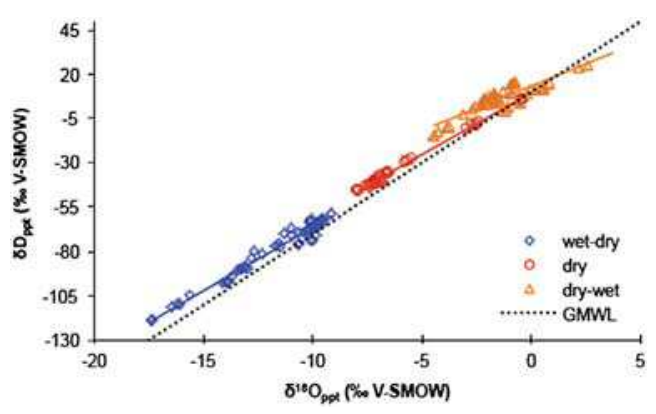

(b)

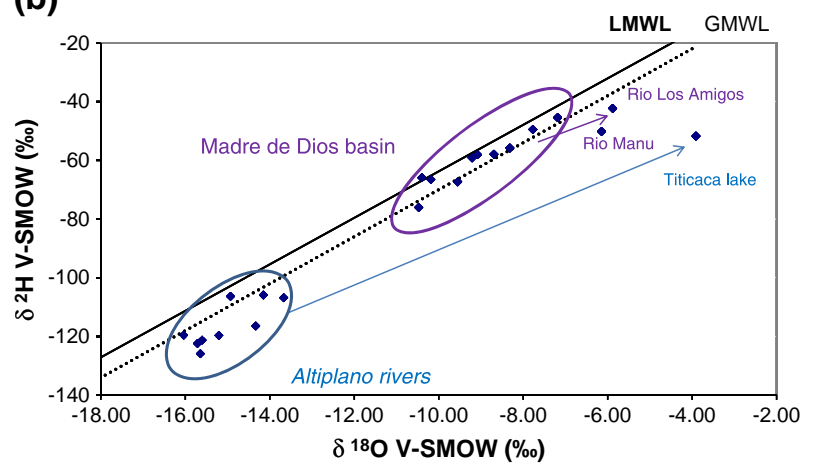

Figure 3. (a) Isotopic characteristics $\left(\delta^{18} \mathrm{O}\right.$ vs. $\left.\delta \mathrm{D}\right)$ of the rainfall over the upper Madre de Dios basin for the different seasons April and October $2009(n=151)$, relative to the Global Meteorite Water Line (GMWL).Wet-dry: April-May, dry June-August, dry-wet: September-October. (b) $\delta^{18} \mathrm{O}$ and $\delta \mathrm{D}$ relationship for the different river waters sampled in August 2009 relative to the GMWL and the Local Meteoric Water Line (LMWL) obtained between April and October 2009.

lower altitude tributaries display lower absolute values $\left(\delta^{18} \mathrm{O}=-6.1\right.$ up to $\left.-5.9 \%\right)$. From these relatively moderate isotopic values, it is clear that the water feeding these river systems is mainly rainfall. On the other hand, in the dry area of the Altiplano rivers, the more depleted $\delta^{18} \mathrm{O}$ values show that more water is coming from snow and glacier melt. For example, the rivers originating in the glacier area of the Cordillera de Vilcanota (Paucartambo and Vilcanato) and the Cordillera de Vilcabamba (Apurimac) show $\delta^{18} \mathrm{O}$ values ranging from -15.7 to $-14.3 \%$. Some very negative values are also found in two other high altitude sites: a spring on the Lake Titicaca island $\left(\delta^{18} \mathrm{O}=-16.0 \%\right.$ ) and Chili River at Arequipa $\left(\delta^{18} \mathrm{O}=-15.6 \%\right)$, which is fed by the Misti glacier.

As seen in Fig. 3(b), most of the Madre de Dios waters are located between the Global Meteoric Water Line (GMWL) and the Local Meteoric Water Line (LMWL) as defined by our rainfall data with a similar slope (7.9 instead of 8.0), but with a higher intercept value (15.5 instead of 10). This can also be seen in Table 1, where the d-excess values range from +12.7 up to +17.3 , which is typical of water vapor recycling by the forest. The rivers close to the LMWL are those which originate in higher altitude areas: Madre de Dios1, Rio Carbone, Rio Aqualiente, and Rio Inambari. By contrast, the only two rivers with lower values than the GMWL are tributaries from the left bank of the Madre de Dios River (the Manú and Los Amigos 
rivers). These tributaries come from lower elevation basins and may be subject to evaporation processes.

On the other hand, the rivers from the Altiplano display higher and more depleted values in heavy isotopes due to glacier melts and high altitude precipitations $\left(\delta^{18} \mathrm{O}=-15.7\right.$ up to $-13.7 \%$ ) but with a high evaporation rate due to altitude dryness (d-excess $=-1.8$ up to +7.3 ). No river water in this area has conductivity values below $300 \mu \mathrm{S} / \mathrm{cm}$. Here, only three points are close to the GMWL and these come from springs or small rivers before any evaporation process can occur: the Rio Ollamtaytambo, a small tributary of the Urubamba coming from the Vilcanota cordillera, the salty spring in Maras and the spring of Isla del Sol on Lake Titicaca, $470 \mathrm{~km}$ further to the south-east. These three values close to the GMWL indicate that the moisture coming from the Amazon forest arrives with almost no evaporation process. The two main tributaries of the Ucayali River (which will become the Amazon River), i.e. the Vilcanota (Urubamba) and Apurimac Rivers, display both high evaporation rates and a high ion load. The water from the Apurimac River is more depleted in heavy isotopes certainly due to the melting water from the Vilcabamba Range glacier, near the Nevado Salkantay peak (6271 m ASL).

The Lake Titicaca water, sampled far from the coast on the Isla del sol (Bolivia), shows the highest evaporation rate. An arrow has been drawn on Fig. 3(b) to display the huge enrichment in heavy isotopes. Although it is mainly fed by glacier melt from the surrounding mountain ranges, this water is rich in the heavy oxygen isotope: $\left(\delta^{18} \mathrm{O}=-3.9 \%\right)$. The conductivity value is also very high $(1300 \mu \mathrm{S} / \mathrm{cm})$ with a high content of sulfate and sodium, as is the d-excess (-20.5). By contrast, spring water from this island displays the most depleted isotopic value $\left(\delta^{18} \mathrm{O}=-16.0 \%\right.$ ) with a d-excess value of 8.8 , close to the
GMWL. There is very little rainfall in this region (around $500 \mathrm{~mm}$ /year), so this spring may originate in an Artesian well within the Cordillera Muñeca, located $45 \mathrm{~km}$ to the north-east, which would explain such a negative $\delta^{18} \mathrm{O}$ value and thus be consistent with its high altitude (3850 m ASL). The Titicaca Lake only feeds the Poopo Lake, which has no river output flowing down to the Pacific Ocean, similar to Salsar. As such, it is an endorrheic system, where water can only disperse by evaporation.

The last water samples came from the Chili River, which is on the Pacific Ocean coast, located above the city of Arequipa, just below the Misti volcano (5822 $\mathrm{m}$ ASL). The isotope ratio value is quite negative $\left(\delta^{18} \mathrm{O}=-15.6 \%\right)$, but the d-excess is very low $(-0.7)$ in this desert area.

Table 2 and the piper diagrams (Figs. 4(a) and 4(b)) report the chemical properties of the studied water samples. The $\mathrm{pH}$ ranges from 6.5 for the Puerto Maldonado area and 7.0 for the foothills, up to 7.7 for the Altiplano. The Madre de Dios sub-basin rivers display the typical low and moderate conductivity of tropical rivers (39-244 $\mu \mathrm{S} / \mathrm{cm}$ ), due to both heavy rainfall and weathered bedrocks. By contrast, nearly all the rivers on the Altiplano have moderate to high conductivity values (193-1301 $\mu \mathrm{S} / \mathrm{cm})$, originating from both soil, evaporation and agricultural activity. Some of the sampled areas contain salt-rich evaporites of marine origin, i.e. halite $(\mathrm{NaCl})$ and gypsite $\left(\mathrm{CaSO}_{4}\right){ }^{[30]}$ and there are also salty springs, such as in Maras, which have been exploited since Inca times. The ion analysis (see Table 2) shows that the Altiplano rivers display an alcaline and a gypsite profile, whereas in the low altitude rivers, calcium carbonate is the predominant form. Different kinds of watersheds can be described using the ternary plots of cations and anions (see Figs. 4(a) and 4(b)), depending on soil geochemistry and anthropogenic activity. The Altiplano river waters plot

Table 2. Concentration of anions and cations in $\mathrm{mg} / \mathrm{L}$

\begin{tabular}{|c|c|c|c|c|c|c|c|c|c|c|c|}
\hline & $\mathrm{F}^{-}$ & $\mathrm{Cl}^{-}$ & $\mathrm{NO}_{2}^{-}$ & $\mathrm{SO}_{4}^{-}$ & $\mathrm{NO}_{3}^{-}$ & $\mathrm{H}-\mathrm{CO}_{3}^{-}$ & $\mathrm{Na}^{+}$ & $\mathrm{NH}_{4}^{+}$ & $\mathrm{K}^{+}$ & $\mathrm{Mg}^{2+}$ & $\mathrm{Ca}^{2+}$ \\
\hline Bosque Nublaco & 0.000 & 1.429 & 0.000 & 0.435 & 0.000 & 21.650 & 4.460 & 0.000 & 1.668 & 1.137 & 8.491 \\
\hline Rio Madre de Dios 1 & 0.158 & 1.384 & 0.000 & 3.481 & 0.000 & 22.387 & 6.037 & 0.234 & 2.883 & 1.750 & 10.445 \\
\hline Rio Carbone & 0.097 & 2.510 & 0.014 & 2.908 & 1.150 & 81.153 & 9.703 & 0.000 & 2.595 & 3.465 & 31.367 \\
\hline Rio Aquacaliente & 0.087 & 1.361 & 0.020 & 3.720 & 0.000 & 32.348 & 5.942 & 0.315 & 1.392 & 2.348 & 16.626 \\
\hline Rio Madre de Dios 2 & 0.102 & 1.394 & 0.014 & 4.189 & 0.000 & 36.969 & 4.757 & 0.000 & 1.199 & 1.647 & 14.101 \\
\hline Rio Manu & 0.095 & 1.333 & 0.013 & 3.064 & 0.000 & 143.033 & 8.380 & 0.107 & 1.719 & 4.278 & 61.721 \\
\hline Rio Colorado & 0.253 & 1.371 & 0.028 & 0.905 & 0.822 & 32.775 & 9.454 & 0.681 & 1.203 & 1.241 & 11.108 \\
\hline Rio Los Amigos & 0.071 & 1.451 & 0.015 & 0.607 & 0.608 & 62.741 & 7.430 & 0.241 & 2.250 & 1.617 & 23.065 \\
\hline Rio Inambari & 0.077 & 1.544 & 0.014 & 3.592 & 0.641 & 20.138 & 5.349 & 0.220 & 1.217 & 1.497 & 9.679 \\
\hline Rio Tambopata & 0.084 & 1.318 & 0.000 & 1.421 & 1.163 & 29.889 & 5.019 & 0.353 & 1.010 & 1.736 & 9.696 \\
\hline Rio Madre de Dios 3 & 0.074 & 1.381 & 0.014 & 2.839 & 0.635 & 47.124 & 6.775 & 0.000 & 1.585 & 2.291 & 19.058 \\
\hline Contamana & 0.101 & 3.542 & 0.000 & 10.862 & 0.916 & 165.105 & 31.998 & 0.000 & 3.953 & 6.379 & 69.758 \\
\hline Vilcanato & 0.100 & 213.860 & 1.110 & 111.289 & 1.065 & 79.567 & 185.200 & 0.000 & 12.403 & 24.145 & 142.036 \\
\hline Colquepata & 0.137 & 25.710 & 0.120 & 22.786 & 0.000 & 80.666 & 46.974 & 0.258 & 2.741 & 15.366 & 21.855 \\
\hline Paucartambo & 0.093 & 11.429 & 0.046 & 42.328 & 0.000 & 50.551 & 18.524 & 0.166 & 2.773 & 9.080 & 54.163 \\
\hline Rio Ollamtaytambo & 0.000 & 1.564 & 0.000 & 21.430 & 1.477 & 139.900 & 8.307 & 0.084 & 1.300 & 17.777 & 54.752 \\
\hline Rio Apurimac & 0.120 & 118.003 & 0.444 & 38.423 & 0.000 & 113.588 & 105.917 & 0.259 & 4.537 & 9.359 & 87.579 \\
\hline rivelet of Rio Apurimac & 0.099 & 1.873 & 0.000 & 22.824 & 1.310 & 106.009 & 31.856 & 0.099 & 3.294 & 11.897 & 67.437 \\
\hline spring Isla del Sol & 0.091 & 5.943 & 0.269 & 0.238 & 4.688 & 90.302 & 8.870 & 0.157 & 1.282 & 9.588 & 61.727 \\
\hline Titicaca Isla del Sol & 0.136 & 313.480 & 1.479 & 109.690 & 0.976 & 121.098 & 294.768 & 0.375 & 24.948 & 38.967 & 89.400 \\
\hline Rio Chili & 0.086 & 21.202 & 0.084 & 9.472 & 0.698 & 57.055 & 25.907 & 0.000 & 5.154 & 4.538 & 19.150 \\
\hline
\end{tabular}


(a)

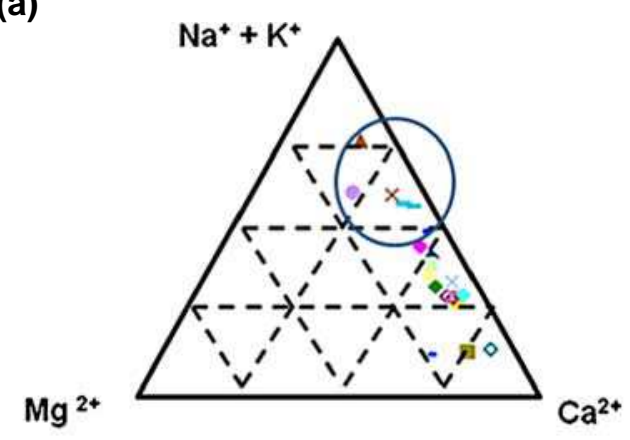

(b)

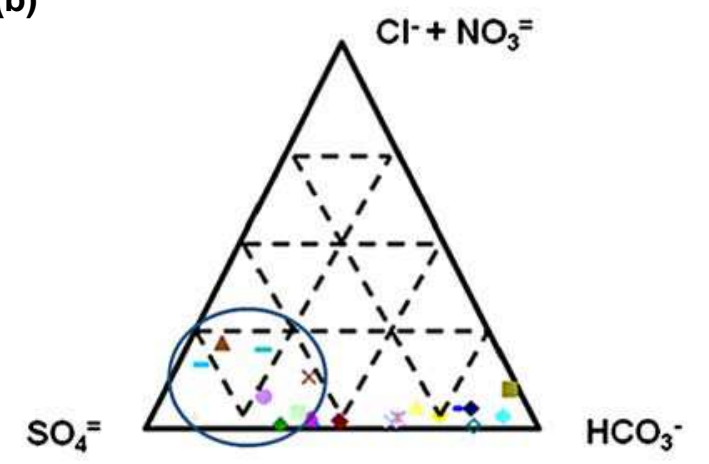

- Bosque Nublaco

- Rio Madre del Dios Rio Carbone

- Rio Aquacaliente

- Rio Madre del Dios

- Rio Manu

- Rio Colorado

Rio Los Amigos

Rio Inambari

Rio Tambopata

Contamana

Rio Madre del Dios

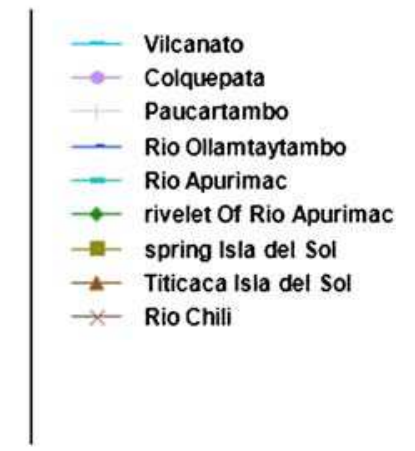

Figure 4. Piper diagrams of (a) the cations and (b) the anions in the river waters, in the circle the main Altiplano samples.

closer to the $\mathrm{Na} / \mathrm{K}-\mathrm{SO}_{4}$ poles, whereas those from the Madre de Dios upper basin are closer to the $\mathrm{Ca}-\mathrm{HCO}_{3}$ pole. An interesting feature is the high levels of sulfate, chlorine, and sodium from the volcanic and/or evaporite area of the Altiplano, mainly in the Vilcanota River and in Lake Titicaca. Even on the eastern side of the Cordillera de Vilcanota, rivers originating from this volcanic range (e.g., Inambari, upper Madre de Dios, and Aguacaliente rivers) display high $\mathrm{SO}_{4}$ values compared with other rivers from the tropical forest side. Rio Carbone and Rio Manú present the highest levels of carbonate, as well as of calcium and magnesium, due to the dolomite/ limestone geological substrate.

Plotting the chloride concentrations against d-excess values (see Fig. 5) makes it easy to distinguish these two watershed systems. Nearly all the water samples from the low Amazonian basin (Madre de Dios upper watershed) are located on the vertical line, i.e. with constant low chloride values and highly variable d-excess values, depending on the recycling/evaporation process along the elevation. Water samples from the Altiplano are located along the decreasing curve, coinciding with the increased chloride concentration in relation with the decreased d-excess. The springs and small rivers are located on the upper left side (i.e. high d-excess values and low chloride concentrations), whereas the bigger rivers with higher evaporation process are on the lower right side (lower d-excess values and high chloride concentrations).

\section{DISCUSSION}

\section{Circulation of the air masses over the Amazon basin}

The marine intertropical convergence zone (ITCZ) brings moisture over the Amazon basin via the north-east trade winds. During the wet austral summer time, the moisture transport between the North Amazon basin and the South La Plata basin is enriched by evapotranspiration from the Amazon forest. During the dry autumn, however, moisture can come from the regions such as subtropical South America-Atlantic sector with less moisture content than the Amazon moist tropical air mass. ${ }^{[22,31]}$ Air parcels supplying precipitation to the Cordillera regions for around 10 days in the wet season usually travel over many thousands of kilometers of tropical forest, over which continental recycling of precipitation occurs. This transition time reaches 14 days or more during the dry season, and as such is more affected by this recycling process. The proportion of precipitation recycled to the atmosphere or lost by runoff has been shown to control continental gradients in $\delta^{18} \mathrm{O}$ values ${ }^{[32]}$ and its variation could affect the rain, snow, and ice composition. ${ }^{[33]}$ Moreover, it has been suggested that processes by which precipitation is recycled (transpiration or evaporation from open water or soil) strongly affect d-excess gradients over the Amazon ${ }^{[7,14,16]}$ and thus possibly the Andean ice core d-excess.

The mechanism of this vapor transit is still in debate as so many factors and different scales can affect it. Nevertheless, some homogeneity can be found between the isotopic rainfall compositions over the central Amazonian Basin at Manaus: ${ }^{[5]}$

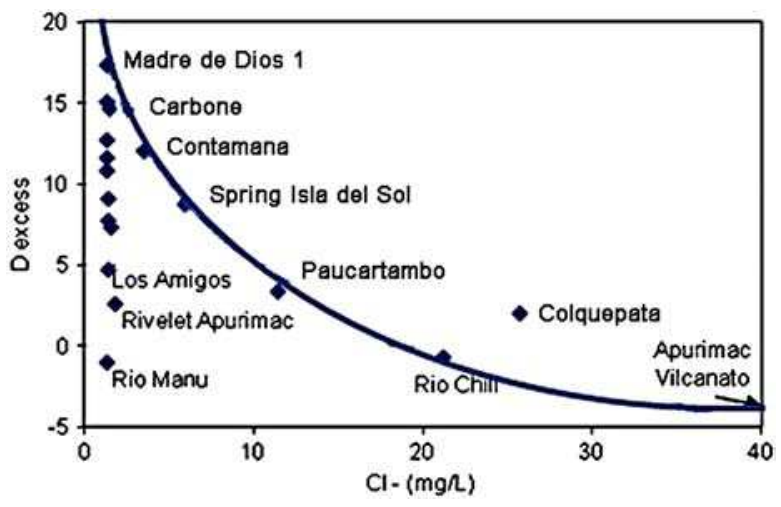

Figure 5. Relationship between the chloride concentration and the d-excess values in Amazon head river waters. 
(1) $\delta \mathrm{D}=7.9 \delta^{18} \mathrm{O}+10$ during the wet season (December to May),

(2) $\delta \mathrm{D}=8.2 \delta^{18} \mathrm{O}+14$ during the dry season (June to November).

From our own data in this study, over the upper Madre de Dios upper basin:

(3) $\delta \mathrm{D}=7.9 \delta^{18} \mathrm{O}+15.5$ during the dry season (April to September).

For the Altiplano glaciers, the values are taken from Hall Birkos: ${ }^{[34]}$

(4) $\delta \mathrm{D}=8.1 \delta^{18} \mathrm{O}+15.9$ : on the Quelccaya glacier (east: Cordillera de Vilconato),

(5) $\delta \mathrm{D}=8.1 \delta^{18} \mathrm{O}+15.5$ on the Coropuna glacier (west: Cordillera occidental).

All the slopes of these five equations are close to 8 , i.e. the slope of the GMWL, indicating no major evaporation process for the rain and no sublimation for the snow deposit at least on the summit. Herreros et al. ${ }^{[39]}$ on the Nevado Coropuna saddle find melting and sublimation on surface ice and snow pits with lower d-excess values.
Equation (1) is really very similar to the GMWL, and Eqns. (2) to (5) have similar higher d-excess values resulting from water recycling through evapo-transpiration and altitudinal effects.

\section{Effect of altitude}

The fog forest growing between 1200 and $3600 \mathrm{~m}$ also has a clear influence on the water recycling and isotopic values. The hydrology of the tropical montane cloud forest is of a specific character and it is very sensitive to climate change and deforestation. The isotopic signature of fogs tends to be more enriched in the heavier isotopes than that of rain due to differences in condensation temperature and history. ${ }^{[35]}$ In Fig. 6(a), we can see how the d-excess values calculated from our rainfall data in the upper Madre de Dios upper basin increased just below the cloud forest zone from 200 to $1500 \mathrm{~m}$, and after reaching a plateau for the higher wet conditions. Gonfiantini et al., ${ }^{[36]}$ who studied the effects of altitude on the isotopic composition of tropical rain, found similar results in Bolivia, with d-excess values ranging from 10 to 20, but with a more linear progression between 500 and $5000 \mathrm{~m}$ due to the absence of cloud forest.

(a)

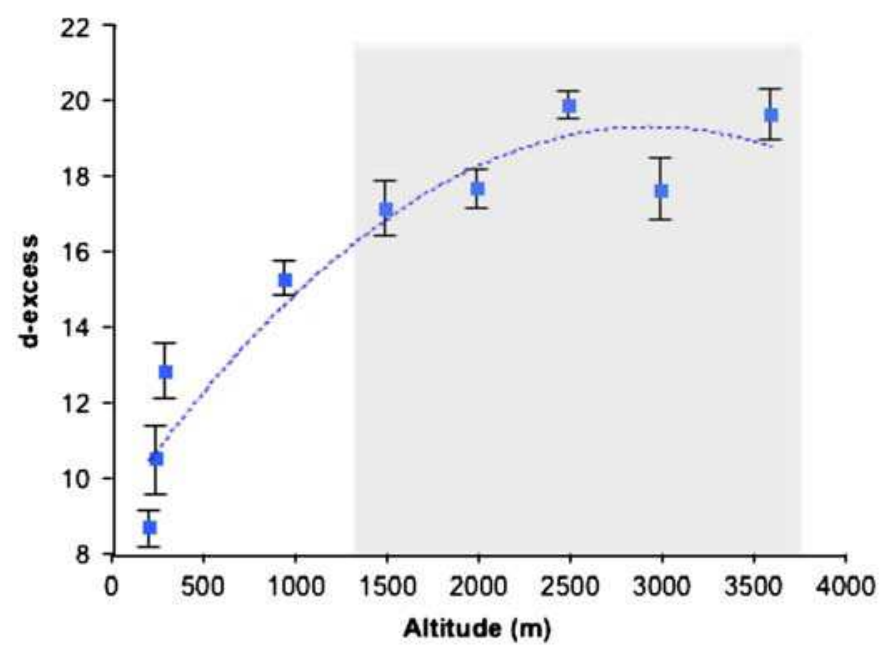

(b)

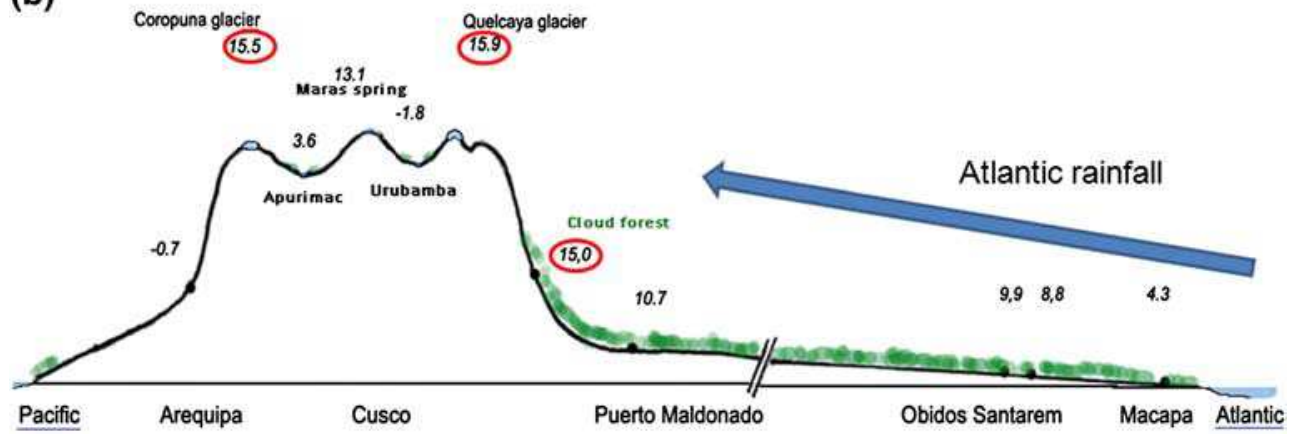

Figure 6. (a) Patterns of d-excess in rainfall in function of altitude along the upper Madre de Dios basin. The grey area corresponds to the cloud forest zone. (b) West-east transect from Arequipa (Peru)to Macapa (Brazil): evolution of the d-excess values of the river waters. The isotope results from October 2003 (Lambs et al. ${ }^{[38]}$ ) are also reported for Obidos, Santarem and Macapa, as well as the glaciers values (Hall Birkos ${ }^{[34]}$ ). Graphic not to scale. 
Temperature then becomes the major factor. At temperatures below zero, the isotopic fractionation in the subsequent vapor condensation on the ice surface deviates from the equilibrium value because the light water molecules may have higher thermal diffusivity. This effect tends to offset the thermodynamic equilibrium by which the isotopically heavy molecules are preferentially fixed in the condensed phase, and may be responsible for the significant increase of the d-excess values.

As we found good correlation between our rainfall data and river sampling over the Madre de Dios upper basin (see Figs. 3(a) and 3(b)), we attempted to obtain an overview of the isotopic gradient along the east-west gradient (see Fig. 6(b)), as suggested from the moisture circulation patterns of Garreaud et al. ${ }^{[37]}$ The $\delta^{18} \mathrm{O}$ values and d-excess are plotted from Macapa (Atlantic Ocean) to Arequipa (Pacific Ocean) in dry season conditions, more or less along the axis of the Madeira River (see Fig. 6(b)). Our own values on the lower Amazon basin from October 2003 ${ }^{[38]}$ were also added, as well as the characteristics of the Quelccaya and Coropuna glacier areas taken from Hall Birkos. ${ }^{[34]}$ These isotopic glacier data are average values over the 1900-2003 period. From east to west, we can see the $\delta^{18} \mathrm{O}$ value decreasing from -3.5 down to $-8.3 \%$, showing in turn the increasing inflow of altitude water. The d-excess is close to the GMWL values of 10 from Obidos up to Puerto Maldonado. In the upper part of the Madre de Dios basin, the Madre de Dios River itself and its tributaries display $\delta^{18} \mathrm{O}$ values around $10 \%$ and d-excess values ranging between +14.5 and +17.3 (see Table 1). Surprisingly, the isotopic ice composition from the two glaciers located on both edges of the Altiplano plateau is similar. Their high $\delta \mathrm{D} / \delta^{18} \mathrm{O}$ slope could indicate the lack of any evaporation/sublimation process during the snow deposit issued from the water vapor coming over the Amazon basin. In fact, the sublimation removes the top ice layer, and thus the enrichment is not seen. However, more recent work $^{[39]}$ has shown that in the Coropuna glacier area, although most of the moisture originates from the tropical Atlantic Ocean, some sporadic marine aerosol can input from the Pacific Ocean. It is also worth noting the high d-excess value $(+13.1)$ found for the Maras Spring in the Vicabamba foothills. All of this suggests a relative homogeneity for the vapor air mass over the Altiplano plateau. Accordingly, the high evaporation rates found for the Apurimac and Vilcanota/Urubamba rivers do not originate from rain or snowfall itself, but from later snow melting and water circulation. By contrast, the low d-excess value ( -0.7$)$ from the Chili River, sampled above Arequipa, shows how distinctive is the dry and warm climate along the Pacific coast.

Lake Titicaca is a special case due to its high rate of evaporation (up to $2000 \mathrm{~mm}$ /year) with less negative isotopic values $\left(\delta^{18} \mathrm{O}=-3.9 \%\right)$ and high d-excess values (over 20). In comparison at a similar altitude, the rainfall over the city of La Paz in Bolivia $(3660 \mathrm{~m})$ displays a mean value over 10 years of $\delta^{18} \mathrm{O}=-12 \%$ and d-excess $=+12 .{ }^{[40]}$ Paredes and Gonfiatini ${ }^{[41]}$ report that $95 \%$ of the water from Lake Titicaca is lost by evaporation, and that the nearby groundwater displays a $\delta^{18} \mathrm{O}$ value of around $-15 \%$, not far from our values on the Isla del Sol spring $(-16 \%)$.

\section{CONCLUSIONS}

In spite of contrasting conditions between the two watersheds, the post-evaporation processes of the Altiplano do not really influence the isotopic composition of the overall Amazon River as the discharge from this dry altitude plateau (200 to $800 \mathrm{~mm} /$ year) is almost completely overshadowed by the rainfall (2000 to $6000 \mathrm{~mm} /$ year), the large Andean foothills and low latitude basin, where the numerous Amazon tributaries become large stream rivers. The wide Amazon basin is where the Atlantic humid air masses move and mix with the evaporated vapor of the 'varzeas' (flooded low-land) and the vapor recycling by the evapo-transpiration process of the huge tropical forest. Most of the heavy precipitation falls on the Andean foothills, and here also the vegetation plays a key role with the montane cloud forest and its permanent fog conditions. The remaining moisture falls on the arid Altiplano plateau, where severe evaporation processes occur due to altitude and coldness.

\section{Acknowledgements}

The SPAM program of the University of Toulouse funded the field party in Peru in 2009. We would like to thank Martin Roddaz (GET, Toulouse) and Stéphane Brusset (GET, Toulouse, and IRD, Lima) for interesting exchange about Amazon hydrology and geology during the field trip, Nelson Gutierrez for his assistance in Puerto Maldonado, and the two anonymous reviewers for their valuable comments and suggestions. Thanks to Victoria McBride for correcting the English.

\section{REFERENCES}

[1] N. A. Villa Nova, E. Salati, E. Matsui. Estimativa da evapotranspiraçao na bacia Amazonica. Acta Amazonica 1976, 6, 215.

[2] Clima, in Geografia do Brasil - Regio Norte, (Ed: E. Nimer), Instituto Brasileiro de Geografia e Estatistica, Rio de Janeiro, 1977, pp.39-58.

[3] J. Marques, J. M. Santos, E. Salati. Consideraçoes sobre os ventos na Regiao Amazonica. Acta Amazonica 1978, 8, 110.

[4] M. N. G. Ribeiro, E. Salati, N. A. Villa Nova, C. G. B. Demetrio. Radiaçao solar disponivel em Manaus esua relaçao com a duraçao de brilho solar. Acta Amazonica 1982, 12, 339.

[5] R. L. Victoria, L. A. Martinelli, J. Mortatti, J. Richey. Mechanism of water recycling in the Amazon Basin: isotopic insights. Ambio 1991, 20, 384.

[6] K. Rozanski, L. Araguás-Araguás. Spatial and temporal variability of stable isotope composition of precipitation over the South American continent. Bull. Inst. Fr. Etudes Andines 1995, 24, 379.

[7] E. Salati, A. D. Olio,E. Matsui, J. R. Gat. Recycling of water in the Amazon Basin: an isotopic study. Water Resources Res. 1979, 15, 1250.

[8] R. R. Leopoldo. Aspetos hidrologicos at florista amazonica denga na regiao de Manaus, $P h D$ thesis, University National Estado San Paolo, Botucato SP, Brasil, 1981.

[9] A. R Townsend, G. P. Asner, J. W. C. White. Land use effects on atmospheric $13 \mathrm{C}$ imply a sizable terrestrial $\mathrm{CO}_{2}$ sink in tropical latitudes. Geophys. Res. Lett. 2002, 29, 10.1029/ 2001GL013454.

[10] E. Matsui, E. Salati, M. N. G. Ribeiro, C. M. Reis, A. C. S. Tancredi, J. R. Gat. Precipitation in the Central 
Amazon Basin: the isotopic composition of rain and atmospheric moisture at Belem and Manaus. Acta Amazonica 1983, 13, 307.

[11] R. E. Dickinson, A. Henderson-Sellers. Modelling tropical deforestation: a study of GCM land-surface parameterizations. Quart. J. Roy. Meteor. Soc. 1988, 114, 439.

[12] A. Henderson-Sellers, V. Gornitz. Possible climatic impacts of land cover transformations, with particular emphasis on tropical deforestation. Climate Change 1984, 6, 231.

[13] J. R. Gat, E. Matsui. Atmospheric water balance in the Amazon Basin: an isotopic evapotranspiration model. J. Geophys. Res. 1991, 96,188.

[14] L. A. Martinelli, R. L. Victoria, L. S. L. Sternberg, A. Ribeirio, M. Z. Moreira. Using stable isotopes to determine sources of evaporated water to the atmosphere in the Amazon basin. J. Hydrol. 1996, 183, 191.

[15] A. Henderson-Sellers, K. McGuffie, H. Zhang. Stable isotopes as validation tools for global climate model predictions of the impact of Amazonian deforestation. J. Climate 2002, 15, 2664.

[16] K. McGuffie, A. Henderson-Sellers. Stable water isotopes reveal Amazon deforestation impacts. J. Geophy.l ResearchAtmospheres 2004, 109, D17104.

[17] H. Paegle. Interactions between convective and large-scale motions over Amazonia, in The Geophysiology of Amazonia, (Ed: R. Dickinson). John Wiley, New York, 1987, pp. 347-387.

[18] J. E. Richey, L. A. Mertes, R. L. Victoria, B. R. Forsberg, T. Dunne, E. Oliveira, A. Tancredi. Sources and routing of the Amazon River floodwave. Global Biogeochem. Cycles 1989, 3, 191.

[19] L. Thompson. Glaciological investigation of the tropical Quelccaya ice cap, Peru, J. Glaciol. 1980, 25, 69.

[20] G. Hoffmann, E. Ramirez, J. D. Taupin, B. Francou, P. Ribstein, R. Delmas, H. Dürr, R. Gallaire, J. Simões, U. Schotterer, M. Stievenard, M. Werner. Coherent isotope history of Andean ice cores over the last century. Geophys. Res. Lett. 2003, 30, 1179.

[21] M. Villacis, F. Vimeux, J-D. Taupin. Analysis of the climate controls on the isotopic composition of precipitation $\left(\delta^{18} \mathrm{O}\right)$ at Nuevo Rocafuerte, $74.5^{\circ} \mathrm{W}, 0.9^{\circ} \mathrm{S}, 250 \mathrm{~m}$, Ecuador C.R. Geosciences 2008, 340, 1.

[22] F. Vimeux, R. Gallaire, S. Bony, G. Hoffmann, J. C. H Chiang. What are the climate controls on $\mathrm{dD}$ in precipitation in the Zongo Valley (Bolivia)? Implications for the Illimani ice core interpretation. Earth Planet. Sci. Lett. 2005, 240, 205.

[23] M. Vuille, R. S. Bradley, M. Werner, R. Healy, F. Keimig. Modeling $\delta^{18} \mathrm{O}$ in precipitation over the tropical Americas: 1. Interannual variability and climatic controls. J. Geophys. Res. 2003, 108, D6.

[24] N. Myers, R. A. Mittermeier, C. G. Mittermeier, G. A. B. da Fonseca, J. Kent. Biodiversity hotspots for conservation priorities. Nature 2000, 403, 853.
[25] Available: http://www.senamhi.gob.pe/.

[26] Available: http://darwin.winston.wfu.edu/andes/.

[27] Available: http://atrium.andesamazon.org/index.php.

[28] H. Craig. Isotopic variation in meteoric waters. Science 1961, $133,1702$.

[29] W. Dansgaard. Stable isotopes in precipitation. Tellus 1964, $16,436$.

[30] M. Goulding, C. Canas, R. Barthem, B. Forsberg, H. Ortega, in Amazon Headwaters, (Ed: W. H. Wust), ACA, Lima, Peru, 2003.

[31] F. Vimeux, G. Tremoy, C. Risi, R. Gallaire. A strong control of the South American SeeSaw on the intra-seasonal variability of the isotopic composition of precipitation in the Bolivian Andes. Earth Planet. Sci. Lett. 2011, 307, 47.

[32] K. Rozanski, L. Araguas-Araguas, R. Gonfiantini. Isotopic patterns in modern global precipitation, in Climate Change in Continental Isotopic Records. Geophysical Monograph, Americal Geophysical Union, 1993, 78, 1.

[33] R. T. Pierrehumbert. Huascarán $\delta^{18} \mathrm{O}$ as an indicator of tropical climate during the Last Glacial Maximum. Geophys. Res. Lett. 1999, 26, 1341.

[34] E. Hall Birkos. Controls on stable oxygen concentrations in Coropuna and Quelccaya Peruvian ice cores over the last 200 years. PhD thesis, University of Ohio, State University, USA, 2009. Available: http://etd.ohiolink.edu/view.cgi? acc_num $=$ osu1238093120.

[35] M. Scholl, W. Eugster, R. Burkard, in Tropical Montane Cloud Forest: Science for Conservation and Management, (Eds: L. A. Bruijnzeel, F. N. Scatena, L. S. Hamilton), Cambridge University Press, Cambridge, 2010, pp. 228-241.

[36] R. Gonfiantini, M-A. Roche, J-C. Olivry, J-C. Fontes, G. M. Zuppi. The altitude effect on the isotopic composition of tropical rains. Chem. Geol. 2001, 181, 147.

[37] R. Garreaud, M. Vuille, A. Clement. The climate of the Altiplano: Observed current conditions and mechanisms of past changes. Palaeogeogr. Palaeoclimatol. Palaeoecol. 2003, 194, 5.

[38] L. Lambs, E. Muller, F. Fromard. The Guianese paradox: How can the freshwater outflow from the Amazon increase the salinity of the Guianan shore? J. Hydrol. 2007, 342, 88.

[39] J. Herreros, I. Moreno, J-D. Taupin, P. Ginot, N. Patris, M. de Angelis, M-P. Ledru, F. Delachaux, U. Schotterer. Environmental records from temperate glacier ice on Nevado Coropuna saddle, southern Peru. Adv. Geosci. 2009, 22, 27.

[40] R. Gallaire, J-D. Taupin, A. Coudrain. Evolution récente des paramètres cryo-climatiques et des teneurs isotopiques des précipitations dans les Andes Boliviennes: La Paz et Glacier du Zongo. Hydrol. Sci. J. 2011, 55, 467.

[41] M. A. Paredes Riveros, R. Gonfiantini. Lake Titicaca: history and current studies. Water Environ. News 1999, 8/9, 6. 